\title{
The Effects of Father's Warm Parenting Behavior on Children's Academic Achievement and School Adjustment During The Transition to Elementary School: The Mediating Role of Children's Peer Play Behavior
}

\author{
Seol Ah Lee ${ }^{1}$, Hee-Jin Yun ${ }^{2}$, Hae Young Kim³ \\ Ph. D. Student, Department of Child \& Family Studies/Human Life Innovation Design, Yonsei University, Seoul, Korea \\ Ph. D. Student, Department of Early Childhood Education, Duksung Womens University, Seoul, Korea ${ }^{2,3}$ \\ 아버지의 온정적 양육행동이 아동의 학업수행능력과 학교적응에 미치는 종단 \\ 적 영향: 유아기 또래놀이행동의 매개효과 \\ 이설아 ${ }^{1}$, 윤희진 ${ }^{2}$, 김혜영 ${ }^{3}$

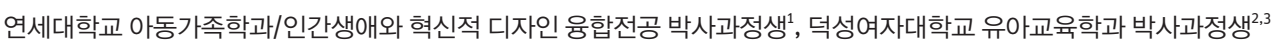

Objectives: Children's "Play" plays a central role in their development, and a father's participation in raising children is as important as a mother's. This study examined the extent to which fathers' parenting behavior with their preschool children influenced their academic achievement and school adjustment through children's' peer play behavior during the period of transition to elementary school. Methods: Using the Panel Study of Korean Children (PSKC), the present study included data on a total of 1,526 children and their father from 2013 (Time 6) to 2015 (Time 8). The hypothesized model was analyzed using structural equation modeling in Mplus 7.31.

Results: Findings indicated that warmth of father's parenting behavior at age five positively influenced children's peer play behavior at age six, increasing interaction and reducing disconnection. It also influenced children's school adjustment at age seven. Results indicated that the effects of the role of father's warm parenting behavior on children's academic achievement and school adjustment were mediated through peer play behavior. These results suggest the importance of father's warm parenting behavior and children's peer play behavior for their academic achievement and school adjustment during the transition to elementary school.

Conclusion: These findings support the proposition that fostering a father's parental warmth and encouraging children's peer play would be a fruitful avenue to promote academic achievement and school adjustment during the transition to elementary school. In other words, this study explains the continuity of development from infancy to early school age and verifies that fathers' parental warmth and children's peer play in infancy are not limited to infancy through a series of long-term developmental pathways. Therefore, to improve school adaptation that affects social and cognitive development after entering elementary school, measures should be presented to support children's play, and to support fathers' warm parenting behavior in the future.

Keywords: parenting behavior, peer play behavior, school adjustment, academic achievement, transition to elementary school, Panel Study of Korean Children

Corresponding Author: Hee-Jin Yun, Ph. D. Student, Department of Early Childhood Education, Duksung Womens University, 33, Samyang-ro 144gil, Dobong-gu, Seoul, Korea

E-mail: ture112@naver.com
(C)The Korean Association of Child Studies

This is an Open Access article distributed under the terms of the Creative Commons Attribution Non-Commercial License (http:// creativecommons.org/licenses/by-nc/4.0) which permits unrestricted noncommercial use, distribution, and reproduction in any medium, provided the original work is properly cited. 


\section{Introduction}

학교적응은 아동이 학교에서 통제력을 가지고 조화를 이루어 가는 경험을 뜻하는 단어로, 이 과정을 통해 아동은 학교에서 접하는 것들을 수용하거나 자신에게 맞게 수정하여 사고한다 (Juvonen \& Wentzel, 1996). 아동의 학교적응은 인간발달에 주 요한 질적 경험이며 아동기 이후의 인지적·정서적·사회적 발 달에 영향을 미친다(D.-H. Jung \& Chi, 2006). 초등학교 1학년 아동의 학교적응은 또래와의 관계, 학업능력, 학습준비도 등 학교생활 전반에 영향을 미치며(E. J. Choi \& Kim, 2020), 학 업성취와도 연관성을 갖는 것으로 보고된다(E. Choi \& Kim, 2019; M. N. Kim \& Lee, 2019; J.-Y. Lee \& Lee, 2019).

학교적응에 관한 연구는 주로 양육 실제에서 어머니와 자 녀 관계에 집중 조명되어 왔다. 그러나 맞벌이 부부가 늘어남 에 따라 아버지와 자녀 간의 질적·양적 접촉의 증가 및 아버지 역할이 점차 확대되면서, 일-가정 양립 정책과 관련 연구에서 아버지 양육의 중요성이 조명되고 있다(J. Choi \& Kim, 2019; H. A. Lee, 2020). 아버지 양육행동은 자녀에게 애정과 관심을 표현하고 자녀의 독립심을 인정하는 자녀와의 의사소통이 높 은 온정적 양육행동과 부모의 규칙과 기대에 따르도록 지도 및 훈육하고 성숙한 행동을 요구하며 부적절한 행동을 규제하 는 통제적 양육행동으로 나누어 구분한다.

아버지의 양육은 자녀의 정서적 안정과 인지능력, 언어발 달, 사회적 상호작용에 긍정적 영향을 미친다(Do, 2013; J. J. Kim \& Park, 2017). 선행연구(K.-H. Lee, 2018)에 따르면 아버 지의 온정적 양육행동은 자녀의 유아기 초기 아버지들 간의 개 인차가 존재하지만, 유아기에서 학령기 전이 시기인 초등학교 1 학년까지 아버지 개인 내 온정적 양육행동은 일관된 수준을 유지하는 것으로 보고한다. 아버지의 온정적 양육행동과 자녀 발달 간의 관계를 탐색한 연구(Grossman et al., 2002)에서는 아 버지가 자녀에게 수행하는 정신적 지지와 놀이파트너, 놀이를 장려하는 격려자 역할이 어머니와 자녀의 관계를 넘어서서, 아 동의 학령기 전이와 학교적응에 영향을 미치는 것으로 나타났 다. 한국아동패널을 사용한 아버지 양육행동과 초등학교 학교 적응 및 학업성취 관련 연구(M. N. Kim \& Lee, 2019; K.-H. Lee, 2018)를 살펴보면, 5-8차년도 아버지의 양육행동은 8차년도 아 동의 초등학교 학교적응에 있어 중요한 요인임이 보고되고 있 다(H.-J. Lee, 2018). 8차년도 아버지의 온정적 양육태도와 학 령기 자녀의 발달에 관한 연구에서는 학교전이 과정에서 초등 학교적응은 학업성취와 연관이 있음을 보고하고 있어(M. N. $\operatorname{Kim} \&$ Lee, 2019), 가정에서 부모의 양육 행동은 자녀의 유아
기 및 학령기 발달과 적응에 영향을 미치는 것을 확인하였다.

한편, 아동이 유아기에 경험하는 놀이는 발달 초기의 사 회화 경험이 일어나는 장이 된다(Vygotsky, 1976). 최근에는 4 차 산업 사회로의 변화에 따라, 몰입을 통한 무한한 가능성을 발현할 수 있는 놀이의 가치가 강조되고 있다(Leurent, Betti, Shook, Fuchs, \& Damrath, 2019). 이처럼 현대 사회에서 놀 이가 더욱 강조되는 이유는 놀이 속에서 이루어지는 대인관 계, 협업능력, 의사소통능력, 문제해결능력, 창의력, 회복탄 력성 등의 경험이 인간의 성장에 중요한 요소이기 때문이다 (Pink, 2006). 유아는 놀이를 통해 또래와의 상호작용이 가장 활발하게 이루어지며, 놀이행동이 곧 유아의 개인적, 발달적 특성을 드러내는 주요 지표이다(Kang, 2016). 유아가 놀이에 서 보여주는 또래상호작용의 행동 특성에 따라 또래놀이행동 은 크게 친사회적이며 놀이를 순조롭게 이어가는 놀이상호 작용(interaction), 공격적이고 부정적인 정서표현인 놀이방해 (disruption), 위축되거나 타인에게 무시나 거부를 당하는 놀 이단절(disconnection) 3가지로 구분된다(Fantuzzo et al., 1995). 또래놀이행동 중 긍정적인 놀이상호작용은 사회적 발달에 긍 정적 영향을 미치는 반면(Bauminger-Zviely, Eytan, Hoshmand, $\&$ Ben-Shlomo, 2019), 놀이단절 행동은 유아의 학습 행동의 일종인, 동기 부여, 주의 지속 학습 태도와 측면에 부정적 영 향을 주는 것으로 나타났다(E. Choi, \& Kim, 2019; Yoo \& Lee, 2019).

유아기 놀이와 초등학교 학교적응이 2019년 개정누리과 정 시행으로 재조명되면서, 놀이에 대한 교육적 가치에 대한 인식이 '놀이'가 초등학교 학습 준비(ready to learn)에 대해서 어떠한 연계성을 지니는지에 관한 연구로 이어지고 있다(E. J. Choi \& Kim, 2020; M.-S. Choi \& Moon, 2020). 유아기 또래 놀이행동은 아동의 사회화 과정에 영향을 주면서(SzewczykSokolowski, Bost, \& Wainwright, 2005), 이후 학교 부적응, 낮 은 학업성취와 밀접한 관련이 있을 가능성이 존재한다. 유아 의 놀이에서 또래 간의 상호작용이 활발하면 친사회성과 또래 유능감 및 적응력이 높게 나타나며(K. Y. Kim \& Lee, 2009; H.J. Lee, 2018; Song \& Lee, 2017), 또래와 협력하고 자신의 의견 을 집단 내에서 적절히 표현하는 능력이 증진되어 학교적응에 중요한 것으로 보고되었다(M.-S. Choi \& Moon, 2020; D.-H. Jung \& Chi, 2006). 유아의 연령이 증가함에 따라 또래와의 상 호작용 시간이 늘어나게 되고, 서로 지식을 공유함으로써 언 어 및 인지발달을 촉진시켜 학업수행능력과 성취를 뒷받침해 준다(M. N. Kim \& Lee, 2019; Shin, Kwon, \& Jeong, 2010). 즉, 유아기 또래놀이행동은 이후의 사회적 능력을 예측할 수 있는 
중요한 요인이며(Howes \& Matheson, 1992; H.-J. Lee, 2018) 이 는 향후 학교적응과 학업성취와도 연관된다.

그러나 대한민국 현실에서 부모들은 놀이의 사회발달적 인 가치에 대해서 동의하지만, 놀이의 무상성(無常性)으로 인 해 초등학교 준비를 위해 놀이보다 학습을 더 가치롭게 여기 는 실정이다(K. C. Kim, Han, \& Kim, 2020). 선행연구에 따르 면, 한국 아동의 또래놀이 상호작용은 만 3세 -5세까지 증가하 다가 초등학교 입학을 앞둔 만 6세 시점에서 감소되었는데, 이 원인으로 초등준비과정에서 놀이보다 학습에 중점을 두기 때 문으로 보았다(H.-J. Lee, 2018). 초등교육을 받을 준비는 유아 기의 충실성에서 비롯되며(D.-H. Jung, 2019), 긍정적 발달을 위해서는 유아기 교육의 핵심 중 하나인 놀이가 충실히 이루 어질 필요성이 제기된다(J.-Y. Lee \& Lee, 2019). 한국아동패널 을 사용한 7차년도 유아의 또래놀이행동이 학업능력과 학습 준비도에 미치는 영향 연구(E. Choi, \& Kim, 2019)에서는 놀 이상호작용이 학업능력 학습준비도에 긍정적 영향을 놀이단 절은 학업능력과 학습준비도에 부정적 영향을 미치는 것으로 나타났다. 7차년도 유아의 또래놀이행동과 8차년도 초등학교 적응 연구(J.-Y. Lee \& Lee, 2019)에서도 학교생활적응과 학업 수행적응, 또래적응에서 유의한 상관이 나타나 유아기 또래놀 이행동과 초등학교적응 간의 긴밀한 연관성을 보여준다. 유아 기 또래놀이행동과 학령기 학교적응에 관해 살펴본 선행연구 들은 유아기 놀이행동과 학령기 학교적응에 큰 영향을 미치 는 가정환경 요인으로 부의 양육행동(Grossman et al., 2002; J. J. Kim \& Park, 2017)을 보고하고 있으며, 양육행동과 또래놀 이행동 간의 관계를 살펴본 연구가 활발히 수행되고 있다. 그 중 아버지 양육행동과 또래놀이행동에 관한 국내 선행연구에 따르면, 만 4세와 만 5 세 유아의 아버지가 자녀와의 관계에 적 극적으로 참여하고 아이의 습관이나 생활에 관심을 가지고 지 도할수록 친사회적 행동이나 대인 간 관계 기술을 사용하는 놀이상호작용이 증가하는 것으로 나타났다(J. J. Kim \& Park, 2017).

선행연구에서 보고된 바와 같이 아버지의 양육행동은 유아 기 사회성 발달 지표인 또래놀이행동과 향후 초등학교적응 및 학업성취에 영향을 미치는 중요한 요인이며, 유아기 또래놀이 행동은 향후 초등학교적응과 학업성취에 예측요인이 될 수 있 다. 그럼에도 국내 선행연구들은 아버지의 양육행동과 유아기 또래놀이행동, 학령기 학교적응 중 각각 두 요인 간의 관계를 탐구하여 가정환경과 유아기 및 학령전이기 발달의 긴밀성을 보여주었을 뿐, 이 세 가지 요인 간의 연관성과 그 과정을 함께 살펴본 연구는 수행되지 않았다. 이에 본 연구에서는 유아기
의 아버지의 양육행동이 유아기와 학령기에 걸쳐 자녀의 발달 에 미치는 영향을 살펴보기 위해 6-8차년도 아동패널 종단데 이터를 이용하여 만 5세 유아기 아버지의 온정적 양육행동과 만 6세 유아기 또래놀이행동, 만 7세 아동기 학교적응 및 학업 성취 간의 관계를 함께 탐색하고자 한다.

한편, 아동의 학교적응과 학업성취에 영향을 미치는 개 인특성 및 환경적 특성인 부모와 가족의 사회인구학적 요인 에 관한 연구에 따르면, 성별에서는 남아보다 여아가 학교적 응 수준(Bae \& Heo, 2019; Jang, Kim \& Song, 2014; C.-I. Kim, 2019; J. Kim \& Hong, 2019; Oh \& Lee, 2019)과 학업수행능력 (J. Kim \& Hong, 2019; Oh \& Lee, 2019)이 높게 나타났다. 부 모의 학력이나 가구소득에 따른 연구(Akçinar, 2013; Park \& Yoo, 2015)에서는 부모의 학력과 가구소득이 학교적응과 학업 성취에 영향을 주는 것으로 나타났다. 따라서 구체적인 연구 모형은 아동의 성별과 아버지의 교육수준, 가구소득을 통제한 상태에서 만 5세 유아기 아버지의 양육행동이 아동의 만 6세 또래놀이행동 발달과 만 7세 취학 후 학업수행능력 및 학교적 응에 직간접적인 영향을 미치는지 종단적으로 분석하고자 한 다. 이를 위해, 본 연구의 연구문제를 다음과 같이 설정하였다.

\section{연구문제 1}

만 5세 아버지의 양육행동은 만 6세 아동의 또래놀이행동과 만 7세 학업수행능력 및 학교적응에 직접적인 영향을 미치는 가?

\section{연구문제 2}

만 5세 아버지의 양육행동이 만 7세 아동의 학업수행능력 및 학교적응에 미치는 영향을 만 6세 또래놀이행동이 매개하는 가?

\section{Methods}

\section{연구대상}

본 연구는 육아정책연구소(Korea Institute of Childcare and Education [KICCE])의 한국아동패널(Panel Study of Korean Children [PSKC]) 6-8차연도(PSKC, 2013; 2014; 2015) 자료를 사용하였다. 한국아동패널은 2008 년 자녀를 출산한 2,150 가 구를 대상으로 아동발달 및 이에 영향을 미치는 가정과 학교 환경을 매해 추적 조사하고 있으며, 6-8차 자료는 유아기 및 
초등학교 전이기를 포함하고 있어 본 연구문제의 분석에 적 합하다. 6차년도(PSKC, 2013) 기준 1,662 가구가 조사에 참여 하여 전체 패널 대비 표본유지율은 $77.3 \%$ 였으며, 이 중 6차년 도 아버지의 온정적 양육행동 및 사회인구학적 변인에 응답 한 아버지와 아동 각각 1,526 명이 최종적으로 분석에 사용되 었다. 최종 연구대상 가구의 아동 평균 월령은 범위 60-66개 월, 평균 62.6 개월 $(S D=1.3)$ 이었으며, 남아 785 명 $(51.4 \%)$, 여 아 741명(48.6\%)이었다. 아버지 평균 연령은 만 38.54세( $S D=$ $4.0)$, 최종학력은 대학교 졸업이 648명(42.5\%)이 가장 많은 것 으로 나타났다. 월평균 가구소득은 201-400만원 이하 772 가구 (50.6\%), 401-600만원 이하 464가구(30.4\%) 순으로 높게 나타 났다.

\section{연구도구}

\section{아버지의 온정적 양육행동}

아버지의 온정적 양육행동은 Cho, Lee, Lee와 Kwon (1999)의 문항을 참고하여 한국아동패널 연구진이 자체 제작한 부모 양 육행동 척도를 이용해 조사되었다. 본래의 척도는 2 개의 하위 영역으로 온정적 양육행동(6문항)과 통제적 양육행동(6문항) 로 구성되어 있으며, 전혀 그렇지 않다(1점)부터 매우 그렇다 (5점)로 구성된 5점 Likert 척도이다. 본 연구에서는 한국아동 패널의 6차년도(PSKC, 2013)에 아동의 아버지에 의해 응답된 자료를 이용하였으며, 아버지의 온정적 양육행동을 주요 변인 으로 사용하였다. 이는 만 5 세 자녀의 유아기에 측정된 아버지 의 온정적 양육행동이 이후 초등학교 1학년까지 일관된 수준 을 유지한다고 보고한 선행연구에 근거하여(K.-H. Lee, 2018), 이 시기에 시간에 따라 변화하지 않는 고정적 특성을 가진 가 족요인으로서 자녀의 만 6세 또래놀이행동 및 만 7세 초등학 교적응과 학업수행능력에 선행한다고 판단하였기 때문이다. 본 연구에서 아버지의 온정적 양육행동의 문항 내적합치도 계 수(Cronbach' $\alpha$ )는 .883으로 나타났다.

\section{또래놀이행동}

유아의 또래놀이행동은 또래놀이행동 척도(Penn Interactive Peer Play Scale [PIPPS])를 이용해 조사되었다. 이는 Fantuzzo, Coolahan, Mendez, McDermott와 Sutton-Smith (1998)가 개발 한 척도를 H. Y. Choi와 Shin (2008)이 국내 아동을 대상으로 타당화 한 것이다. 본 척도는 본래 놀이상호작용(9문항), 놀이
방해(13문항), 놀이단절(8문항)의 3개 하위영역으로 구성되었 으며, 전혀 그렇지 않다(1)부터 항상 그렇다(4)로 구성된 4점 Likert척도이다. 본 연구에서는 한국아동패널 7차년도(PSKC, 2014)에 아동의 육아지원기관의 담임교사가 평정한 자료를 사용하였다. 이는 초등교육을 받을 준비로써 유아기의 충실성 (D.-H. Jung, 2019), 즉 유아기 교육의 핵심 중 하나인 놀이가 충실히 이루어져야 할 필요성이 제기됨(J.-Y. Lee \& Lee, 2019) 에 따라 학령기 전이 과정인 초등입학 전 만 6세의 또래놀이행 동이 초등학교 1학년 만7세 학교적응과 학업수행능력에 미치 는 영향을 살펴보고자 하였다. 본 척도의 문항 내적합치도 계 수(Cronbach' $\alpha$ )는 놀이상호작용 .803과 놀이단절 .888, 놀이 방해 .876으로 나타났다.

\section{학업수행능력}

아동의 학업수행능력은 E. H. Lee 등(2008)이 개발한 학업 수 행 능력 척도를 한국아동패널(PSKC, 2017)에서 재인용하여 조사한 것이다. 국어(4문항), 수학(5문항), 학업전반(1문항)의 세 가지 하위영역으로 구성되어 있으며, 하위 $20 \%$ 이하(1점) 부터 상위 20\%이상(5점)으로 측정된 5점 Likert척도이다. 한 국아동패널 8차년도(PSKC, 2015)에 초등학교 1학년인 아동 의 담임교사가 평정한 자료를 사용하였다. 학업수행능력은 초 등학교 1 학년 아동의 학교적응과 학습태도 및 학업수행능력 간의 밀접한 관계가 선행연구들에서 보고되어왔다(E. Choi \& Kim, 2019; M. N. Kim \& Lee, 2019; J.-Y. Lee \& Lee, 2019). 1 문 항으로 구성된 학업전반은 문항의 내적합치도 분석을 수행하 지 않았다. 국어와 수학의 문항 내적합치도 계수(Cronbach' $\alpha$ ) 는 각각 .941과 .979로 나타났다.

\section{학교적응}

아동의 학교적응은 D.-H. Jung과 Chi (2006)의 학교적응 척도 를 사용하여 조사되었다. 이 척도는 국내 초등학교 1학년 아 동의 학교적응을 측정하기 위해 개발한 것으로 학교생활 적응 (11문항), 학업수행적응(11문항), 또래적응(8문항), 교사적응 (5문항)으로 4 개의 하위영역으로 구성된다. 전혀 그렇지 않다 (1점)부터 항상 그렇다(5점)로 구성된 5점 Likert척도이다. 본 연구에서는 한국아동패널 8차년도(PSKC, 2015)에 초등학교 1 학년인 아동의 담임교사가 평정한 자료를 사용하였으며, 이는 초등학교 1학년 아동의 학교적응이 이후 교사 및 또래와의 관 계와 학습 태도 및 학업성취에 걸친 학교생활 전반에 영향을 
미치는 것으로 나타나(E. Choi $\&$ Kim, 2019; E. J. Choi \& Kim, 2020; M. N. Kim, \& Lee, 2019; J.-Y. Lee \& Lee, 2019), 학령기 전이에서 중요한 발달 예측요인이기 때문이다. 그러나 본 척 도의 평정자가 교사임을 고려하여 교사와의 $1: 1$ 관계 적응에 관한 문항인 교사적응을 제외한 나머지 세 개의 하위영역을 최종 모형에 사용하였다. 사용된 하위영역의 문항 내적합치도 계수(Cronbach' $\alpha$ )는 학교생활적응 .959, 학업수행적응 .944, 또래적응.944으로 나타났다.

\section{통제변인}

아동과 아동이 속한 가족의 사회인구학적 요인은 아동의 학교 적응 및 학업성취에 밀접한 관련이 있는 것으로 알려져 왔다 (Bae \& Heo, 2019; Jang, Kim, \& Song, 2014). 이에 본 연구에서 는 아동의 개인특성으로 성별을, 가족특성으로 아버지의 교육 수준과 월평균 가구 소득을 통제변인으로 포함하였다. 한국아 동패널 6차년도(PSKC, 2013)에 조사된 자료를 이용하였으며, 본 연구에서는 아동의 성별은 남아(0), 여아(1)로 코딩하였다. 아버지의 교육수준은 무학(1), 초등학교 졸업(2), 중학교 졸업 (3), 고등학교 졸업(4), 전문대 졸업(5), 대학교 졸업(6), 대학원 졸업(7)로 코딩하였다. 월평균 가구 소득은 만원 단위로 응답 되었으며, 자연로그값으로 변환하여 모형에 포함하였다.

\section{자료분석}

본 연구는 SPSS 22.0 (IBM Co., Armonk, NY)과 Mplus 7.31 (Muthén \& Muthén, 2012)프로그램을 이용하여 자료를 분석 하였다. 먼저 SPSS 22.0으로 연구대상의 일반적 특성을 확인 하기 위하여 아버지와 아동의 사회인구학적 요인에 관한 빈도 분석 및 기술통계를 수행하였다. 다음으로 측정도구의 신뢰 도 검증을 위한 문항 내적합치도 계수를 산출하였다. 사전 분 석으로는 상관분석을 수행하여 주요 변인 간 상관관계를 살 펴보았으며, 주요 변인의 정규분포를 살펴보기 위해 왜도 및 첨도 값을 확인하였다. 이후에 Mplus 7.31 프로그램을 이용하 여 구조방정식 모형(Structural Equation Modeling [SEM])을 이 용하여 최종 모형을 분석하였고, 연구 자료의 결측치는 최대 우도법(Maximum Likelihood [ML])를 통해 처리되었다. 모형 의 적합도 판별을 위해서 $\chi^{2}, \mathrm{CFI}, \mathrm{TLI}, \mathrm{RMSEA}$ 지수를 이용하 였는데, $\chi^{2}$ 는 표본 크기에 민감하므로 이외의 모형 적합 지수 를 함께 고려하였다(Hong, 2000). CFI와 TLI는 .90이상이면 좋은 적합도(Bentler, 1990), RMSEA는 .05미만이면 좋은 적합
도, .08미만이면 괜찮은 적합도(Browne \& Cudeck, 1992)로 판 단하였다. 매개경로의 효과를 확인하기 위하여 부트스트래핑 (bootstrapping) 기법을 이용하였다. 부트스트래핑 결과는 $95 \%$ 신뢰구간 안에 0이 포함되지 않으면 통계적으로 유의한 것으 로 간주하였다(MacKinnon, Lockwood, \& Williams, 2004).

\section{Results}

\section{사전분석}

주요 분석에 앞서 아버지의 온정적 양육행동과 아동의 또래놀 이행동, 학업수행능력, 학교적응 각 하위영역의 기술통계를 통해 일반적 경향을 살펴보고, 왜도 및 첨도를 통한 정규성 분 포를 확인하였다. 이에 관한 결과는 Table 1에 제시되었다. 먼 저 주요 변인의 왜도 값은 $-1.46 \sim 1.16$, 첨도 값은 -.04 1.93으 로 나타났으며, 왜도와 첨도의 절대값이 각각 3 과 8 보다 작아 정규성 분포 가정을 충족하였다(Kline, 2015). 다음으로 변인 간 상관관계를 살펴보기 위해 Pearson의 상관계수를 산출한 결 과는 다음과 같이 나타났다. 아버지의 온정적 양육행동은 매 개변수인 아동의 또래놀이행동 중 놀이상호작용과 정적 상관 을 $(r=.07, p<.05)$, 놀이단절은 부적 상관을 보였으나 $(r=-.08$, $p<.01)$, 놀이방해와의 상관관계는 유의하지 않았다. 아버지 의 온정적 양육행동과 종속변수인 학업수행능력의 학업전반 $(r=.11, p<.05)$, 국어 $(r=.10, p<.01)$, 수학 $(r=.10, p<.01)$ 및 학교적응의 학교생활적응 $(r=.10, p<.01)$, 학업수행적응 $(r=$ $.09, p<.01)$, 또래적응 $(r=.13, p<.01)$ 과도 각각 정적 상관관 계가 있는 것으로 나타났다.

아동의 또래놀이행동 중 놀이상호작용은 종속변수인 학업 수행능력의 학업전반 $(r=.18, p<.01)$, 국어 $(r=.20, p<.01)$, 수 학 $(r=.16, p<.01)$ 및 학교적응의 학교생활적응 $(r=.21, p<.01)$, 학업수행적응 $(r=.27, p<.01)$, 또래적응 $(r=.25, p<.01)$ 과 각각 정적 상관관계가 있는 것으로 나타났다. 아동의 또래놀이행동 중 놀이단절은 학업수행능력의 학업전반 $(r=-.20, p<.01)$, 국어 $(r=-.23, p<.01)$, 수학 $(r=-.22, p<.01)$ 및 학교적응의 학교생활 적응 $(r=-.17, p<.01)$, 학업수행적응 $(r=-.20, p<.01)$, 또래적응 $(r=-.21, p<.01)$ 과도 각각 부적 상관관계에 있는 것으로 나타 났다. 마지막으로 아동의 또래놀이행동 중 놀이방해는 학업수 행능력의 학업전반 $(r=-.18, p<.01)$, 국어 $(r=-.17, p<.01)$, 수학 $(r=-.17, p<.01)$ 및 학교적응의 학교생활적응 $(r=-.35, p<.01)$, 학업수행적응 $(r=-.24, p<.01)$, 또래적응 $(r=-.13, p<.01)$ 과도 
Table 1

Means, Standard Deviations, and Correlations Among Variables

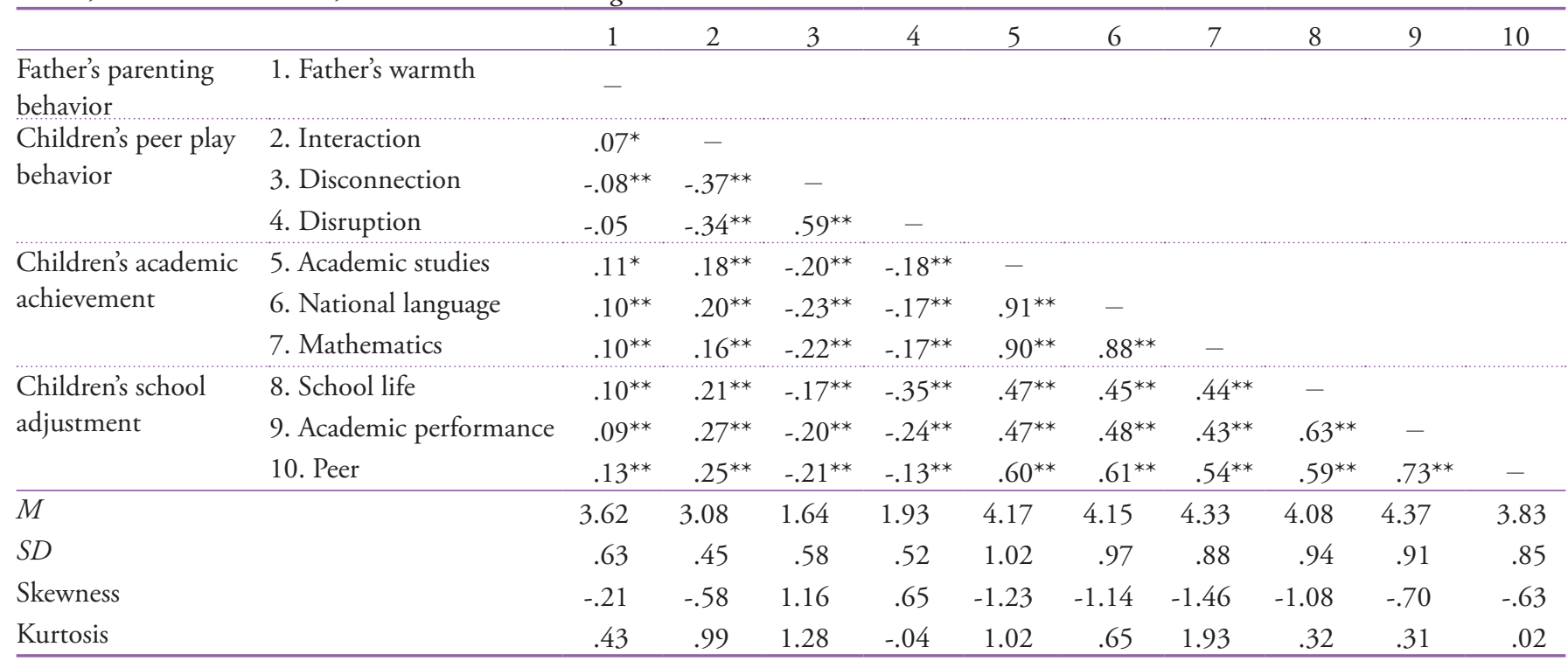

${ }^{*} p<.05 .{ }^{* *} p<.01$.

각각 부적 상관관계에 있는 것으로 나타났다.

\section{주요분석}

아버지의 온정적 양육행동, 또래놀이행동, 학업 수행능력 및 학교적응

본 연구에서는 아버지의 온정적 양육행동과 아동의 유아기 또 래놀이행동, 초등학교 학업수행능력 및 학교적응 간의 직간접 관계를 종단적으로 살펴보기 위해 구조방정식 모형을 수행하 였다. 연구모형의 적합도는 $\chi^{2}=411.834(d f=45, p<.001)$, CFI $=.941, \mathrm{TLI}=.906, \mathrm{RMSEA}=.073$ 로 나타났으며, 최종 모형은 Figure 1 에 제시되었다. 아동의 학업수행능력과 학교적응 잠 재변인을 구성하는 측정 변인의 요인 적재치를 먼저 살펴보면 다음과 같다. 학업수행능력의 측정변인인 학업전반 $(\beta=.964$, $p<.001)$, 국어 $(\beta=.944, p<.001)$, 수학 $(\beta=.927, p<.001)$ 은 요인적재치가 모두 높은 수준으로 나타났다. 또한 학교적응의 학교생활적응 $(\beta=.718, p<.001)$, 학업수행적응 $(\beta=.866, p<$ $.001)$, 또래적응 $(\beta=.835, p<.001)$ 요인적재치가 모두 높은 수 준으로 나타났다.

변인 간 경로를 살펴보면, 아버지의 온정적 양육행동은 아동의 유아기 또래놀이행동 놀이상호작용에 정적으로 $(\beta=$ $.066, p<.05)$, 놀이단절에는 부적으로 유의한 영향을 미치는 것으로 나타났으며 $(\beta=-.082, p<.01)$, 초등학교 1 학년 학교
적응에 정적인 영향을 미치는 것으로 나타났다 $(\beta=.097, p<$ .01). 즉, 아버지 양육행동이 온정적일수록 아동의 유아기 또 래놀이행동에서 놀이상호작용을 높이고 놀이단절을 낮추며, 초등학교 1학년 학교적응을 높이는 것으로 나타났다. 그러나 아버지의 온정적 양육행동이 아동의 유아기 또래놀이행동의 놀이방해와 초등학교 1학년 학업수행능력에 미치는 영향은 유의하지 않은 것으로 나타났다.

아동의 유아기 또래놀이행동이 이후 초등학교 학업수행능 력과 학교적응에 미치는 영향에서 먼저 놀이상호작용은 학업 수행능력 $(\beta=.103, p<.05)$ 과 학교적응 $(\beta=.225, p<.001)$ 에 유 의한 정적 영향을 미치는 것으로 나타났으며, 놀이단절은 학업 수행능력 $(\beta=-.189, p<.001)$ 과 학교적응 $(\beta=-.113, p<.05)$ 에 유 의한 부적 영향을 미치는 것으로 나타났다. 즉, 아동의 유아기 또래놀이행동 놀이상호작용은 이후 초등학교 1학년 학업수행 능력 및 학교적응을 높이고, 놀이단절은 학업수행능력 및 학교 적응을 낮추는 것으로 나타났다. 그러나 아동의 유아기 또래놀 이행동의 놀이방해가 초등학교 1학년 학업수행능력과 학교적 응에 미치는 영향은 유의하지 않은 것으로 나타났다.

\section{또래놀이행동의 매개효과}

아버지의 온정적 양육행동이 아동의 초등학교 학업수행능력 및 학교적응에 미치는 영향에서 만6세 또래놀이행동의 매개효 과에 관한 결과는 Table 2 와 같다. 먼저 아버지의 온정적 양육행 


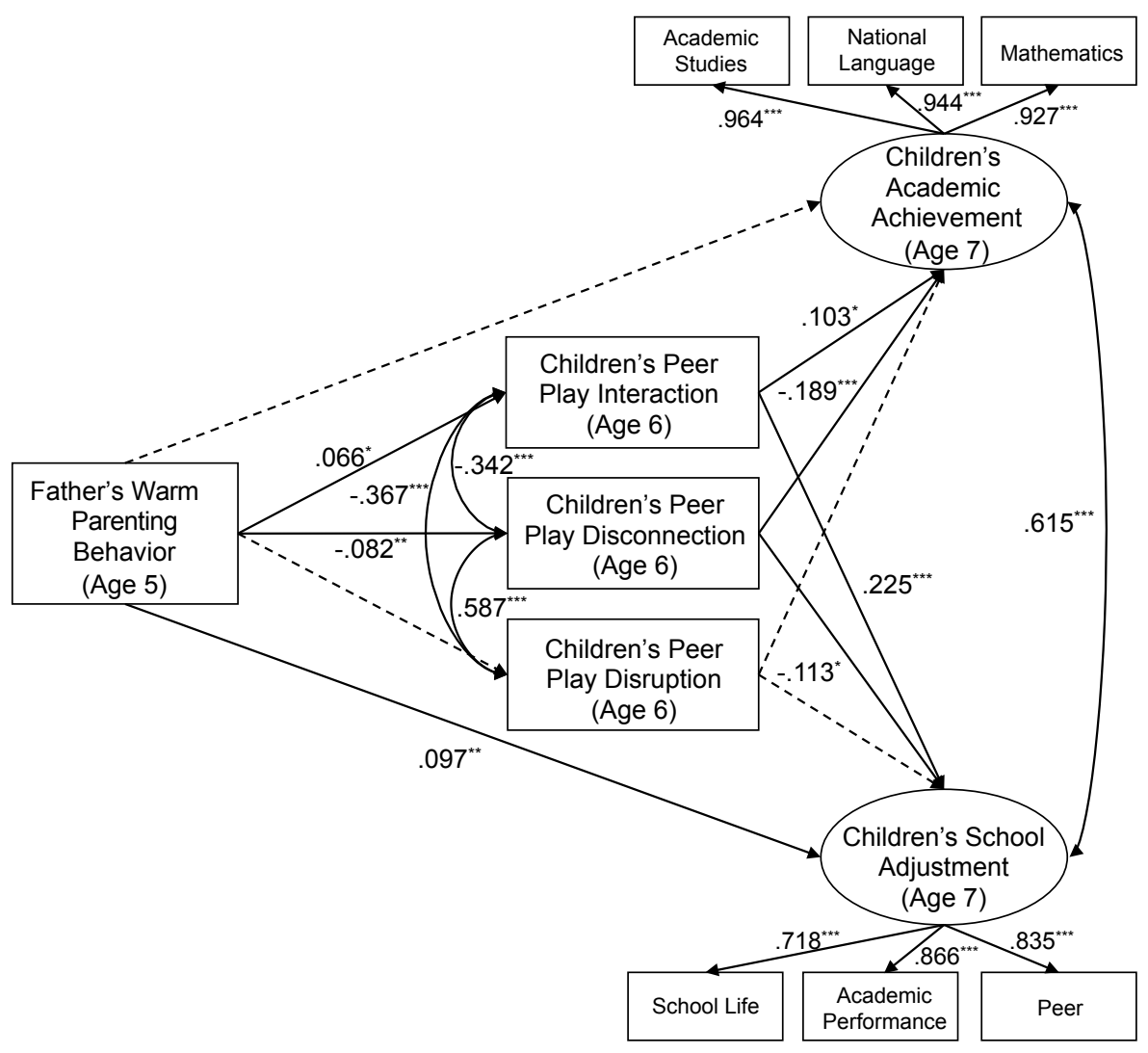

Figure 1. Path model of the mediating effects of children's peer play on the relationship between father's warm parenting behavior and children's academic achievement and school adjustment. Standardized coefficient are presented.

${ }^{*} p<.05 .{ }^{* *} p<.01 .{ }^{* * *} p<.001$.

Table 2

Indirect Effects of Father's Warm Parenting Behavior on Children's Academic Achievement and School Adjustment with Children's Peer Play Behavior as Mediators

\begin{tabular}{|c|c|c|c|c|c|c|c|}
\hline & & & & & & & o C.I. \\
\hline & & & th & & $\beta$ & Lower & Upper \\
\hline $\begin{array}{l}\text { Father's warm } \\
\text { parenting behavior }\end{array}$ & $\rightarrow$ & $\begin{array}{l}\text { Children's peer play } \\
\text { behavior }\end{array}$ & $\begin{array}{l}\text { Interaction } \\
\text { Disconnection } \\
\text { Disruption }\end{array}$ & $\begin{aligned} & \rightarrow \text { Children's academic } \\
& \text { achievement }\end{aligned}$ & $\begin{array}{r}.007 \\
.016 \\
-.001 \\
\end{array}$ & $\begin{array}{r}.001 \\
.007 \\
-.018\end{array}$ & $\begin{array}{l}.033 \\
.057 \\
.005\end{array}$ \\
\hline & & $\begin{array}{l}\text { Children's peer play } \\
\text { behavio }\end{array}$ & $\begin{array}{l}\text { Interaction } \\
\text { Disconnection } \\
\text { Disruption }\end{array}$ & $\begin{array}{l}\text { Children's school } \\
\text { adjustment }\end{array}$ & $\begin{array}{l}.015 \\
.009 \\
.003\end{array}$ & $\begin{array}{r}.003 \\
.002 \\
-.003\end{array}$ & $\begin{array}{l}.058 \\
.042 \\
.027\end{array}$ \\
\hline
\end{tabular}

동이 아동의 초등학교 학업수행능력 미치는 영향은 유아기 또 래놀이행동 놀이상호작용에 의해 매개되었으며 $(\beta=.007,95 \%$ C.I. = .001 .033), 놀이단절에 의해서도 매개되는 것으로 나타 났다 $(\beta=.016,95 \%$ C.I. $=.007 \sim .057)$. 또한, 아버지의 온정적 양육행동이 아동의 초등학교 학교적응에 미치는 영향도 유아 기 또래놀이행동 놀이상호작용에 의해 매개되었으며 $(\beta=.015$, $95 \%$ C.I. $=.003-.058)$, 놀이단절에 의해서도 매개되는 것으로 나타났다 $(\beta=.009,95 \%$ C.I. $=.002-.042)$. 즉, 아버지의 양육행
동이 온정적일수록 아동의 유아기 또래놀이행동에서 놀이상호 작용을 높이고 놀이단절을 낮추어, 이후 초등학교 1학년 학업 수행능력과 학교적응을 높이는 것으로 나타났다. 그러나 아버 지의 온정적 양육행동이 아동의 초등학교 1학년 학업수행능력 과 학교적응에 미치는 영향에서 유아기 또래놀이행동 놀이방 해의 매개효과는 유의하지 않은 것으로 나타났다. 


\section{Discussion}

본 연구에서는 한국아동패널연구 자료를 이용하여 만 5 세 유아 기 아버지의 양육행동이 아동의 만 6 세 또래놀이행동 발달과 만 7세 취학 후 학업수행능력 및 학교적응에 미치는 직간접적인 영 향을 살펴보았다. 주요 결과를 요약하고 논의하면 다음과 같다.

주요 변인 간의 관계에서 나타난 직접적 영향을 먼저 살펴 보면 첫째, 만 5세 아버지의 온정적 양육행동은 아동의 만 6세 유아기 또래놀이행동 중 놀이상호작용을 증진하고 놀이단절 을 감소시키는 것으로 나타났다. 만 5 세 아버지의 온정적 양육 행동으로 만 6세 아동의 긍정적 놀이행동 증가와 부정적 놀이 행동 감소가 나타난 본 연구결과는 Lipscomb (2011)의 만 4-5 세 유아는 아버지의 온정적 양육행동 속에서 타인과 협력하 는 태도와 행동을 배우고 연습하게 된다는 연구를 뒷받침한 다. 또한 만 2 세 아버지의 온정적 양육행동이 이후 만 4 세 유 아의 또래놀이행동에 긍정적 영향을 미치며(Suh, 2017), 아버 지 양육행동이 유아의 놀이성에 긍정적 영향을 미친다는 연구 (Chung, Yee, \& Kang, 2017)와 같은 맥락으로 볼 수 있다.

둘째, 만 5 세 아버지의 온정적 양육행동은 아동의 만 7세 학 교적응에 긍정적 영향을 미치는 것으로 나타났다. 이는 유아 기 아버지의 반응적이고 온정적인 양육행동이 이후 아동의 학 령기 전이와 학교적응에 긍정적 영향을 미치는 것으로 나타난 기존 연구(Allhusen et al., 2004; Grossman et al., 2002; H.-J. Lee, 2018)와 같은 결과이다. 그러나 학업수행능력에는 직접적 영 향을 미치지 않는 것으로 나타나 아버지의 온정적 양육태도와 학령기 자녀의 발달에 관한 선행연구들이 학령기 전이 과정에 서 초등학교적응 및 학업성취 모두와 연관이 있음을 보고한 것(E. Choi \& Kim, 2019; M. N. Kim \& Lee, 2019; J.-Y. Lee \& Lee, 2019)과는 다른 결과이다.

셋째, 아동의 만 6세 또래놀이행동 중 놀이상호작용은 만 7 세 학업수행능력 및 학교적응을 증진하지만, 놀이단절은 학령 기 전이에 부정적 영향을 미치는 것으로 나타났다. 이는 유아기 또래놀이행동 중 놀이상호작용이 사회적 발달에 긍정적인 영향 을 미친다는 보고(Bauminger-Zviely et al., 2019)와 일치한다. 즉, 놀이에서 또래 간의 상호작용이 활발하면 친사회성과 또래유능 감 및 적응력이 높게 나타날 뿐만 아니라(K. Y. Kim \& Lee, 2009; H.-J. Lee, 2018; Song \& Lee, 2017), 또래와 협력하고 자신의 의견 을 집단 내에서 적절히 표현할 수 있으므로 이 같은 특성이 향후 학교적응에도 긍정적 영향을 주는 것이다(M.-S. Choi \& Moon, 2020; D.-H. Jung \& Chi, 2006). 또한, 놀이단절이 동기 부여, 주 의 지속, 학습 태도 등 학습 행동과 연관된 행동에 부정적 영향
을 미쳐(E. Choi \& Kim, 2019; Yoo \& Lee, 2019), 부적응 및 낮은 학업성취와 밀접한 관련이 있을 가능성을 제기한 연구(E. J. Choi $\&$ Kim, 2020; M. N. Kim \& Lee, 2019)와도 같은 맥락이다.

다음으로 만 5 세 아버지의 온정적 양육행동이 만 7세 아동 의 초등학교적응과 학업성취에 미치는 영향은 만 6 세 유아기 또래놀이행동을 통해 매개되는 것으로 나타났다. 먼저 아버지 의 온정적 양육행동이 아동의 초등학교 학업수행능력에 미치 는 영향은 각각 유아기 놀이상호작용과 놀이단절을 통해 완전 매개되는 것으로 나타났다. 즉, 만 5 세 아버지의 온정적 양육 행동이 높을수록 아동의 만 6세 친사회적이며 놀이를 순조롭 게 이어가는 놀이상호작용 행동이 증가하고 위축되거나 타인 에게 무시 또는 거부당하는 특징인 놀이단절 행동이 감소하 며, 이를 통해 만 7세 학업수행능력을 높이는데 긍정적 영향을 미친다. 선행연구는 아버지의 양육행동이 자녀의 정서적 안정 과 사회적 상호작용 등 사회정서적 측면은 물론, 언어발달 및 인지능력 측면에도 긍정적 영향을 미치는 것으로 나타났으나 (Do, 2013; J. J. Kim \& Park, 2017), 본 연구에서는 아버지의 온 정적 양육행동이 인지능력과 언어발달에 해당하는 학업수행 능력에 미치는 직접적 영향이 나타나지 않았다. 이는 아버지 의 양육행동과 아동의 학업성취 간의 메커니즘, 즉 아버지의 온정적 양육행동과 학령기 전이 과정에서의 학업성취 연관성 (E. Choi \& Kim, 2019; M. N. Kim \& Lee, 2019; J.-Y. Lee \& Lee, 2019)이 유아기의 긍정적인 또래놀이행동 증진과 부정적 또 래놀이행동 감소를 통해 나타난 결과임을 보여준다.

마지막으로 아버지의 온정적 양육행동이 아동의 초등학교 학교적응에 미치는 영향은 각각 유아기 놀이상호작용 증가와 놀이단절 감소를 통해 부분매개되는 것으로 나타났다. 즉, 만 5 세 아버지의 온정적 양육행동이 높을수록 아동의 만 6세 친 사회적이며 놀이를 순조롭게 이어가는 놀이상호작용을 증진 하고 위축되거나 타인에게 무시 또는 거부당하는 특징인 놀 이단절을 감소시키며, 이는 만 7세 아동의 학교적응을 돕는 다. 이를 통해 아버지의 정신적 지지와 격려자 역할이 놀이행 동 자체뿐만 아니라(J. J. Kim, \& Park, 2017; K. S. Kim \& Park, 2002), 이후 아동의 학교적응에도 영향을 미치는것(Grossman et al., 2002)으로 나타나 아버지 양육행동, 유아기 또래놀이행 동, 학령기 학교적응의 종단적 영향을 확인하였다.

종합하면 만 5세 아버지의 온정적 양육행동과 아동의 만 7세 아동의 학교적응 및 학업수행능력 간의 관계에서 만 6세 놀이 상호작용과 놀이단절의 매개효과가 확인되었다. 이는 유아기의 부모 양육행동과 아동의 또래놀이행동이 유아기에 국한되어 영 향을 미치는 것이 아니라, 취학과정을 거쳐 초등학교 진학 후 학 
교적응 및 학업수행으로 이어지는 일련의 종단적인 발달경로를 보여준다. 또한, 이 과정에서 아동의 또래놀이행동 중 놀이상호 작용과 놀이단절은 각각 초등학교 단계에서 사회적으로 성공적 인 학교적응과 더불어 인지적 측면에서의 언어와 수학 학업성취 발달을 강화하거나 저해하는 요인임이 밝혀졌다.

따라서 본 연구결과는 놀이보다는 학습을 더 가치롭게 여기 고 있는 학령 전 유아를 둔 부모(K. C. Kim, Han \& Kim, 2020) 를 대상으로 하여 유아기 놀이의 중요성을 인식하고 이를 강화 하는 정책적 근거가 될 수 있을 것이다. 또한 아버지의 온정적 양육행동은 아동이 성장하는 유아기와 학령기 발달에 중요한 영향요인 중 하나로 볼 수 있으므로 또래놀이행동에 긍정적 영 향을 줄 수 있는 아버지의 반응적이고 수용적인 온정적 양육행 동 증진과 놀이를 지원하는 구체적인 가정연계 프로그램 개발 및 지원의 필요성이 제기된다. 이를 통해 부모들에게 유아기 또래놀이 지원은 초등학교 입학 이후 학령기 아동의 전인적 발 달지표인 학교적응 및 학업수행능력 향상에 중요한 요인임을 안내하고, 유아기 자녀를 둔 아버지의 온정적 양육행동 수행을 지원하는 방안이 함께 마련되어야 할 것이다.

마지막으로 본 연구의 한계점과 후속연구를 위한 제언은 다음과 같다. 첫 번째로, 만 5세 아버지 온정적 양육행동과 만 7세 학업수행능력 및 학교적응과의 관계에서 만 6세 놀이방 해의 직간접적 영향이 없는 것으로 나타났으므로 향후 유아 기 또래놀이행동 중 놀이방해와 아버지 양육행동, 학업수행능 력 및 학교적응 간의 연관성을 확인하기 위하여 해당 변인에 관한 연구가 수행되어야 할 것이다. 두 번째로, 본 연구에서는 온정적 양육행동에 초점을 맞추어 아동의 학령기 전이에 따른 부모의 양육행동의 변화(Collins, Madsen, \& Susman-stillman, 2002)를 충분히 설명하지 못하므로 향후에는 아버지의 양육 행동의 통제적 측면을 포함하여 유아기와 학령기 전반의 아버 지 양육행동이 아동의 학교적응 및 학업수행능력에 미치는 영 향을 살펴볼 필요성이 제기된다. 세 번째로, 초등학교적응에 관한 연구들은 아동의 집행기능문제 및 내재화.외재화 문제 등을 포함하여 학령기 발달을 살펴보고 있으므로(Seo \& Kim, 2018), 후속연구에서는 다양한 학교생활 관련 변인을 통해 아 동의 학교적응을 통합적으로 살펴보아야 할 것이다.

\section{Notes}

This article was presented at the 11th Conference of the Panel Study on Korean Children.

\section{Conflict of Interest}

No potential conflict of interest relevant to this article was reported.

\section{References}

\section{In English}

Akçinar, B. (2013). The predictors of school adaptation in early childhood. Procedia-Social and Behavioral Sciences, 93, 1099-1104. doi:10.1016/j.sbspro.2013.09.338

Allhusen, V., Belsky, J., Booth-LaForce, C., Bradley, R., Brownell, C. A., Burchinal, M.,...Houts, R. (2004). Fathers' and mothers' parenting behavior and beliefs as predictors of children's social adjustment in the transition to school. Journal of Family Psychology, 18(4), 628-638. doi:10.1037/08933200.18.4.628

Bauminger-Zviely, N., Eytan, D., Hoshmand, S., \& Ben-Shlomo, O. R. (2019). Preschool Peer Social Intervention (PPSI) to enhance social play, interaction, and conversation: Study outcomes. Journal of Autism and Developmental Disorders, 50(3), 844-863. doi:10.1007/s10803-019-04316-2

Bentler, P. M. (1990). Comparative fit indexes in structural models. Psychological bulletin, 107(2), 238-246. doi:10.1037/00332909.107.2.238

Browne, M. W., \& Cudeck, R. (1992). Alternative ways of assessing model fit. Sociological Methods \& Research, 21(2), 230-258. doi:10.1177/0049124192021002005

Collins, W. A., Madsen, S. D., \& Susman-Stillman, A. (2002). Parenting during middle childhood. In M. H. Bornstein (Ed.), Handbook of parenting: Children and parenting (2nd ed., Vol. 1, pp. 73-101). Mahwah, NJ: Lawrence Erlbaum Associates Publishers.

Fantuzzo, J., Sutton-Smith, B., Coolahan, K. C., Manz, P. H., Canning, S., \& Debnam, D. (1995). Assessment of preschool play interaction behaviors in young low-income children: Penn interactive peer play scale. Early Childhood Research Quarterly, 10(1), 105-120. doi:10.1016/08852006(95)90028-4

Grossmann, K., Grossmann, K. E., Fremmer-Bombik, E., Kindler, H., Scheuerer-Englisch, H., \& Zimmermann, P. (2002). The uniqueness of the child-father attachment relationship: Fathers' sensitive and challenging play as a pivotal variable in a 16-year longitudinal study. Social development, 11(3), 301-337. doi:10.1111/1467-9507.00202

Howes, C., \& Matheson, C. C. (1992). Sequences in the 
development of competent play with peers: Social and social pretend play. Developmental Psychology, 28(5), 961974. doi:10.1037/0012-1649.28.5.961

Juvonen, J., \& Wentzel, K. (1996). Social motivation: Understanding children's school adjustment. New York: Cambridge University Press.

Kline, R. B. (2015). Principles and practice of structural equation modeling (4th ed.). New York: The Guilford Press.

Leurent, H., Betti, F., Shook, E., Fuchs, R., \& Damrath, F. (2019). Leading through the fourth industrial revolution: Putting people at the centre. World Economic Forum, Geneva, Swizerland. Retrieved from http://www3.weforum.org/ docs/WEF_Leading_through_the_Fourth_Industrial_ Revolution.pdf

Lipscomb, R. C. (2011). Strategies to improve fathers' involvement with their children's development and academic achievement. Race, Gender \& Class, 18(3-4), 253-267.

MacKinnon, D. P., Lockwood, C. M., \& Williams, J. (2004). Confidence limits for the indirect effect: Distribution of the product and resampling methods. Multivariate Behavioral Research, 39(1), 99-128. doi:10.1207/s 15327906 mbr3901_4

Mplus (Version 7.31). [Computer software]. Los Angeles, CA: Muthén \& Muthén.

Pink, D. H. (2006). A whole new mind: Why right-brainers will rule the future. New York: Riverhead Books.

Szewczyk-Sokolowski, M., Bost, K. K., \& Wainwright, A. B. (2005). Attachment, temperament, and preschool children's peer acceptance. Social Development, 14(3), 379-397. doi:10.1111/j.1467-9507.2005.00307.x

Vygotsky, L. S. (1976). Play and its role in the mental development of the child. In J. S. Brunner, A. Jolly, \& K. Sylva (Eds.), Play: Its role in the development and evolution (pp. 863-895). London: Penguin Books.

\section{In Korean}

Bae, H., \& Heo, C.-A. (2019). Differences in school adjustment to first grade according to latent profiles of home environments. Korean Journal of Child Care and Education Policy, 13(1), 75-99. doi:10.5718/kcep.2019.13.1.75

Cho, B., Lee, J., Lee, H., \& Kwon, H. K. (1999). Dimensions and assessment of Korean parenting style. Journal of the Korean Home Economics Association, 37(10), 123-133.

Choi, E., \& Kim, E. (2019). The effect of child's peer-play interaction characteristics on academic ability and school readiness. Journal of Learner-Centered Curriculum and Instruction, 19(1), 1333-1353. doi: 10.22251/jlcci.2019. 19.1.1333

Choi, E. J., \& Kim, K. J. (2020). The effect of child's peer- play interaction characteristics on self-esteem and school adjustment at first grade of elementary school. Journal of Future Early Childhood Education, 27(2), 215-234. doi:10.22155/JFECE.27.2.215.234

Choi, H. Y., \& Shin, H. Y. (2008). Validation of the Penn Interactive Peer Play Scale for Korean children. Korean Journal of Child Studies, 29(3), 303-318.

Choi, J., \& Kim, H. K. (2019). Family-friendly policies in fathers' workplaces and subjective happiness of fathers, mothers, and children. Korean Journal of Child Care and Education Policy, 13(2), 145-169. doi:10.5718/kcep.2019.13.2.145

Choi, M.-S., \& Moon, I.-J. (2020). The effect of young children's playfulness and resilience on school readiness. The Journal of Child Education, 29(2), 231-247. doi:10.17643/ KJCE.2020.29.2.12

Chung, M., Yee, B., \& Kang, S. (2017). The effect of father's playfulness on children's creative behavior: The mediated effect of father's parenting behavior and playfulness of the children. Korean Journal of Early Childhood Education, 37(5), 413-434. doi:10.18023/kjece.2017.37.5.018

Do, N. H. (2013). Abeojiui yangyukchamyeoreul wihan siljiljeok jiwondaechaek piryo [아버지의 양육참여를 위한 실질적 지원대책 필요]. KICCE Policy Brief, 17, 1-4.

Hong, S. (2000). The criteria for selecting appropriate fit indices in structural equation modeling and their rationales. Korean Journal of Clinical Psychology, 19(1), 161-177.

Jang, H.-J., Kim, E.-S., \& Song, S.-Y. (2014). Difference on children's school adjustment by children's personal and family background variables. The Journal of Elementary Education, 27(2), 95-122.

Jung, D.-H. (2019). Review for application of UN SDG 4.2 on early childhood education. The Journal of Korea Open Assoociation for Early Childhood Education, 24(6), 375-393. doi:10.20437/KOAECE24-6-14

Jung, D.-H., \& Chi, S.-A. (2006). A study of the relationships among children's peer interactions, child-teacher relationships, multiple intelligences, and elementary school adjustment. Korean Journal of Early Childhood Education, 26(3), 201-221.

Kang, M. J. (2016). An exploration of the meaning about play freechoice activities for early childhood teacher. The Journal of Korean Teacher Education, 33(3), 189-211. doi:10.24211/ tjkte.2016.33.3.189

Kim, C.-I. (2019). A study of factors influencing school adjustment of the first grade elementary school student: Focusing on characteristics of children, parents, and teachers. The Korean Journal Child Education, 28(4), 171-187. doi:10.17643/ KJCE.2019.28.4.10

Kim, J., \& Hong, S. (2019). An analysis of factors affecting the school adjustment in elementary school students. The 
Journal of Learner-Centered Curriculum and Instruction, 19(6), 699-719. doi:10.22251/jlcci.2019.19.6.699

Kim, J. J., \& Park, H. S. (2017). The effects of father's play beliefs on play flow and peer play behavior of young children, with particular focus on the mediating effects of father's play participation. Korean Journal of Child Education and Care, 17(3), 29-48. doi:10.21213/kjcec.2017.17.3.29

Kim, K. C., Han, Y. J., \& Kim, I. A. (2020). The images of play beliefs of parents expressed through young children's drawings. The Journal of Korea Open Association for Early Childhood Education, 25(3), 301-331. doi:10.20437/ KOAECE25-3-13

Kim, K. S., \& Park I. J. (2002). The relationship between fathers' rearing behaviors, playfulness, and young children's playfulness. Korean Journal of Play Therapy, 5(2), 27-43.

Kim, K. Y., \& Lee, J.-H. (2009). The relationship among young children's solitary play, temperament, and peer competence. Korean Journal of Social Science, 28(1), 243-261. doi:10.18284/jss.2009.06.28.1.243

Kim, M. N., \& Lee, W. J. (2019). The association between preschoolers' peer play behaviors and academic abilities at primary school: A two-year longitudinal study. Journal of Korean Council for Children \& Rights, 23(1), 111-129. doi: $10.21459 / \mathrm{kccr} .2019 .23 .1 .111$

Lee, H. A. (2020). Effect analysis of the fatherhood programs provided in healthy family and multicultural support center. Contemparary Society and Multiculture, 10(2), 143175. doi:10.35281/cms.2020.05.10.2.143

Lee, H.-J. (2018). The predictive factors of preschoolers' peer play interaction trajectories and the effects on first grade elementary childrens' peer adjustment. Journal of Education of Culture, 24(3), 387-408. doi:10.24159/joec.2018. 24.3.387

Lee, J.-Y., \& Lee, S.-H. (2019). Effect of individual variables, children's peer interactions, social competence, and children's problem behavior on school adjustment. Journal of Early Childhood Education \& Educare Welfare, 23(3), 171-199. doi:10.22590/ecee.2019.23.3.171

Lee, K.-H. (2018). A longitudinal study among early childhood variables influencing school adjustment. The Journal of Korea Open Association for Early Childhood Education, 23(6), 399-425. doi:10.20437/KOAECE23-6-17

Oh, S., \& Lee, S. (2019). Effects of childhood development on the application of primary school 1 st grade by gender. The Journal of Child Education, 28(3), 135-149. doi:10.17643/ KJCE.2019.28.3.07

Panel Study on Korean Children. (2013). Panel study of Korean children 6th survey [Data file and codebook]. Retrieved from https://panel.kicce.re.kr

Panel Study on Korean Children. (2014). Panel study of Korean children 7th survey [Data file and codebook]. Retrieved from https://panel.kicce.re.kr

Panel Study on Korean Children. (2015). Panel study of Korean children 8th survey [Data file and codebook]. Retrieved from https://panel.kicce.re.kr

Panel Study on Korean Children. (2017). Academic achievement [Profile Tool]. Retrieved from https://panel.kicce.re.k

Park, I., \& Yoo, J. P. (2015). The impact of household income and maternal employment on school adjustment of children: The mediating effects of parental educational involvement. Journal of Youth Welfare, 17(3), 157-186.

Seo, J. W., \& Kim, H. K. (2018). Developmental pathways to school adjustment and executive function during the transition to elementary school: The role of mothers' involvement and children's social skills. Korean Journal of Early Childhood Education, 38(5), 107-130. doi:10.18023/ kjece.2018.38.5.005

Shin, E. S., Kwon, M. K., \& Jeong, H. B. (2010). The relationships between social skills, peer play interactions and social play behaviors. Journal of Future Early Childhood Education, 17(4), 183-209.

Song, J., \& Lee, S. (2017). The role of parents' child-rearing behavior and teacher-child interaction in peer interaction: The mediating role of social skills. Korean Journal of Early Childhood Education, 37(5), 507-531. doi:10.18023/ kjece.2017.37.5.022

Suh, G. W. (2017). The Influence of marital satisfaction on child's peer-play behavior and problem behavior: The mediated effects of father's and mother's parenting behavior. Korean Journal of Child Studies, 38(6), 79-91. doi:10.5723/ kjcs.2017.38.6.79

Yoo, M.-H., \& Lee, K.-N. (2019). The structural relationships among teacher-child interaction, young children's academic skills, peer play interaction and school readiness. Journal of Future Early Childhood Education, 26(2), 1-23. doi:10.22155/JFECE.26.2.1.23

\section{ORCID}

$\begin{array}{ll}\text { Seol Ah Lee } & \text { https://orcid.org/0000-0002-3755-7027 } \\ \text { Hee-Jin Yun } & \text { https://orcid.org/0000-0001-6169-7460 } \\ \text { Hae Young Kim } & \text { https://orcid.org/0000-0003-0505-2910 }\end{array}$

Received February 28, 2021

Revision received April 27, 2021

Accepted May 31, 2021 